\title{
Productive potential of upland rice under conventional and organic farming systems
}

Janice Regina Gmach' Cileide Maria Medeiros Coelho²*, Círio Parizotto ${ }^{3}$, Isaac Heberle², Heitor Amadeu Prezzi², André Tesser Mafioleti ${ }^{4}$, Clovis Arruda Souza ${ }^{2}$, David José Miquelluti²

\author{
'Federal Institute of Santa Catarina, São Miguel do Oeste, SC , Brasil \\ 2University of the State of Santa Catarina, Lages, SC , Brasil \\ ${ }^{3}$ Company of Agricultural Research and Rural Extension of Santa Catarina, Campos Novos, SC , Brasil \\ ${ }^{4}$ University of Western Santa Catarina, Campos Novos, SC, Brasil \\ *Corresponding author, e-mail: cileide.souza@udesc.br
}

\begin{abstract}
This paper aimed to evaluate the genetic diversity of upland rice varieties, determine the components that contributes most to productivity and evaluate the yield of varieties grown in conventional and organic farming systems. The experiment was carried out during the 2011/2012, 2012/2013 and 2013/2014 crop years, with 11 local upland rice varieties (Agulha, Rosa 15, Mato Grosso, Gomes, Preto, Argentino, Kinsel, Camilo, Piriquito, Casca Roxa and Caipira) and two commercial varieties (Primavera and Cambará). Genetic diversity was observed among the varieties for all evaluated variables and the thousand grain weight was the character that contributed most to the divergence between varieties. The number of panicles $\mathrm{m}^{-2}$ was the yield component that presented the highest association with grain yield of varieties in organic farming systems. The average yield of the varieties was $2.303,1.711$ and $3.534 \mathrm{~kg} \mathrm{ha}^{-1}$ for the seasons 1, 2 and 3 respectively, and the highest yields were obtained with earlier sowing and temperature during grains maturation about $20^{\circ} \mathrm{C}$. The 'Piriquito', 'Argentino', 'Gomes' and 'Kinsel' varieties presented yield above $2.000 \mathrm{~kg} \mathrm{ha}^{-1}$ for all seasons, in both systems, indicating better adaptation to the region of the study and can be indicated as the most promising for the crop under organic cultivation.
\end{abstract}

Keywords: characterization, genetic variability, path analysis

\section{Introduction}

The rice growth in Brazil has been realized in an upland and lowlands (Alvarez et al., 2012). The upland cultivation is the most representative when the number of states is taken in consideration, with higher production at the the midwest region of Brazil (EMBRAPA ARROZ E FEIJÃO, 2016).

In the Santa Catarina state, the upland rice can be produced throughout the state. Nowadays 400 ha are been cultivated, with the grain yield about of $1900 \mathrm{~kg} \mathrm{ha}^{-1}$ (EMBRAPA ARROZ E FEIJÃO, 2016). This crop has been replaced by other crops, due to the low yield and profitability, mainly due to the lack of adopted varieties to these growing conditions.

The state is characterized by the predominance of family growers, and the rescue of local varieties represents an alternative for these growers, as well as studies that could identify productive varieties, with good quality and adapted to cultivation of the region, both under conventional and organic systems. The conventional farming system uses synthetic fertilizers and pesticides derived from nonrenewable energy sources and is a nonsustainable production model. The organic system is based on specific production standards that establish sustainable structures from the social, ecological, and economic point of view. 
Productivity is a complex character, resulting from the expression and association of different components, which should be considered in variety selection (Amorim et al., 2008). In rice, it is defined by the number of panicles per area, number of grains per panicle and grain weight (Marchezan et al., 2005). The variety yield also depends on the conditions offered for its development (Menezes et al., 2011), so the evaluation of the performance of the varieties based on only one year and one local of cultivation may be inefficient due to the variability of response to the local environmental conditions according to the years and growing seasons. In this way, the presence of interaction between the locations, years and seasons of cultivation is expected (Cargnelutti Filho et al. 2006).

It is known that there is great genetic diversity and different varieties cultivated in the world. However, the use of local varieties of rice is limited and has been replaced by improved cultivars with a smaller genetic base, limiting the use of biodiversity in a sustainable way.

Considering that the cultivation of local varieties provides the conservation of the genetic resources, it is necessary to study and characterize these materials according to the agronomic interests and climate influences in the different years of cultivation, making feasible the use by the growers of the region. The aim of this study was to evaluate the genetic diversity among upland rice varieties, determine the yield components that contribute most to productivity, and to evaluate the varieties yield in conventional and organic growing systems.

\section{Material and Methods}

The experiments were conducted during the following crop years: $2011 / 2012,2012 / 2013$ and 2013/2014 (vintages/harvests 1, 2 and 3 respectively), in upland conditions, at the Epagri Experimental Station-Campos Novos-SC. During the harvest 1 , varieties under organic system were characterized and during the harvests 2 and 3 , the organic and conventional systems were evaluated. The treatments consisted of 11 local varieties (Agulha, Rosa 15, Mato Grosso, Gomes, Preto, Argentino, Kinsel, Camilo, Piriquito, Casca Roxa and Caipira) and two comercial varieties
(Primavera and Cambará).

For the organic cultivation, the organic fertilization was realized with poultry manure, in a similar amount as the region growers used to apply. During the first period of cultivation, $10+$ $\mathrm{ha}^{-1}$ (dry bases) were used, being $5 \mathrm{th}^{-1}$ after the incorporation of the winter cover, $1.7 \mathrm{tha}^{-1}$ at sowing and $3.3+\mathrm{ha}^{-1}$ on cover, at 50 days after emergence. During the second and thirty cultivations, 5 t ha- were applied, being 1.7 t ha $^{-1}$ at sowing and $3.3 \mathrm{tha}^{-1}$ on cover. During the first year of growing, a higher amount was used to correct the lower soil fertility. Each ton of poultry manure provided $10 \mathrm{Kg}$ of $\mathrm{N}, 30 \mathrm{KG}$ of $\mathrm{P}$ and 16 $\mathrm{kg}$ of $\mathrm{K}$ to the soil. For the conventional system, the fertilization was realized considering a crop productive potential of $2.000 \mathrm{~kg} \mathrm{ha}^{-1}$, according to the soil analysis. For the first year of cultivation, $112 \mathrm{~kg} \mathrm{ha}^{-1}$ of the formula 5-20-10 was used during sowing and $65 \mathrm{~kg} \mathrm{ha}^{-1}$ of urea on cover at 50 days after emergence.

For the first year, the experiment was conducted under field conditions, in randomized blocks, with four repetitions. During the second and thirty years of cultivation, a completely randomized block design was used in the arrangement of subdivided plots with four repetitions per treatment. Conventional and organic systems were the main plots, while the varieties delimited the subplots. The experimental units were composed of four lines of $4 \mathrm{~m}$ in length, spaced $0.5 \mathrm{~m}$. As a useful area, the two central lines were used, eliminating $0.5 \mathrm{~m}$ at each end. The sowing was manually performed with 100 grains $\mathrm{m}^{2}$ of density, on 10/10/2011, 10/20/2012 and $10 / 09 / 2013$.

For both systems, weed control throughout the experiment was performed manually whenever necessary. Due to the irregular distribution of rainfall in the municipality, irrigation was used, when necessary, through a fixed conventional sprinkler irrigation system with a precipitation of $8.0 \mathrm{~mm}$ hour-1, providing a water depth of $16 \mathrm{~mm}$.

The meteorological data of rainfall, maximum, average and minimum temperature, and relative humidity were collected during the experiment conduction at the Epagri Meteorological Station of Campos Novos - SC, 
located near the experimental area.

The evaluated agronomic characteristics were: number of tillers $\mathrm{m}^{2}$; plant height; panicle length; flowering; cycle; number of viable panicles $\mathrm{m}^{2}$; number of grains per panicle; grain yield; thousand grains weight; percentage of filled grains per panicle. The plots were manually harvested according to difference stage of the cycle of each variety, considering $50 \%$ of the panicles with the mature grains.

In the obtained results, the normality and homogeneity of variances were evaluated. Based on the tests, it was necessary to apply the $\sqrt{ }$ transformation to the variables emergence, tillering, flowering, cycle, number of viable panicles, panicles $\mathrm{m}^{2}$, and number of grains per panicle. Also the arc-sine transformation was applied to the variable percentage of full grains. The results were submitted to variance analysis by the F's test and the means of the varieties were compared using the Scott-Knott's test, and among the cultivation systems by the Tukey's test. The comparison of the yield of the local varieties with the commercial varieties was performed using the Dunnett's test. In order to evaluate the degree of association of yield components and agronomic traits with productivity and to measure the relative importance of each variable on yield in the $1^{\text {st }}$ crop year, path analysis was performed according to a causal diagram in two chains, where productivity was considered as the basic variable. In the first chain the components of the yield were considered as primary variables and in the second the other variables were considered as secondary variables. The varieties were grouped according to the Tocher optimization method, taking as a measure of dissimilarity the generalized distance of Mahalanobis and the relative importance of the characters was determined based on the Singh's methodology (1981). The analyses were conducted with the aid of the GENES software (Cruz, 2008). For all performed tests, a minimum significance level of $5 \%$ was considered.

\section{Results and Discussion}

Experiment $1-1^{\text {st }}$ crop year: characterization and productivity of upland rice varieties cultivated in organic system

The mean yield of the varieties was 2.303 $\mathrm{kg} \mathrm{ha}^{-1}$, higher than the mean yield achieved in the Santa Catarina State $\left(1.400 \mathrm{~kg} \mathrm{ha}^{-1}\right)$. Higher yields were observed for the varieties 'Piriquito' $14.106 \mathrm{~kg}$ ha $^{-1}$ ), 'Argentino' (3.638 kg ha-1), 'Gomes' (3.367 $\mathrm{kg} \mathrm{ha}^{-1}$ ) and 'Camilo' (3.361 kg ha-') (Table 1). The mean yield was also higher than the observed by Gonçalves et al. (2011), with 17 local upland rice varieties at the west region of the Santa Catarina State, Brazil, where the mean observed was 1.720 $\mathrm{kg} \mathrm{ha}^{-1}$. It is possible that those differences were attributed to the additional irrigation applied in this present research. Other authors related that the occurrence of hydric deficiency during the flowering period resulted in lower grain yield, which is very important for higher upland rice yields (Guimarães et al., 2011) .

Most of the local varieties presented higher yield than the commercial ones, and only

Table 1. Agronomic characterization of upland 13 rice varieties under organic cultivation, Campos Novos, SC, Brazil, $2011 / 2012$ crop year

\begin{tabular}{lcccccccc}
\hline \multicolumn{1}{c}{ Variety } & TIL & HEI & PAL & CYC & NPM & PFG & TGM & Y \\
\hline Agulha & $74 \mathrm{~b}$ & $78 \mathrm{c}$ & $21 \mathrm{~b}$ & $191 \mathrm{c}$ & $107 \mathrm{c}$ & $80 \mathrm{~b}$ & $25.3 \mathrm{~h}$ & $1.216 \mathrm{~d}$ \\
Rosa 15 & $40 \mathrm{c}$ & $84 \mathrm{c}$ & $22 \mathrm{a}$ & $192 \mathrm{c}$ & $108 \mathrm{c}$ & $88 \mathrm{a}$ & $27.7 \mathrm{e}$ & $1.190 \mathrm{~d}$ \\
Mato Grosso & $82 \mathrm{~b}$ & $82 \mathrm{c}$ & $20 \mathrm{~b}$ & $195 \mathrm{~b}$ & $173 \mathrm{a}$ & $90 \mathrm{a}$ & $28.8 \mathrm{~d}$ & $2.127 \mathrm{c}$ \\
Gomes & $117 \mathrm{a}$ & $102 \mathrm{a}$ & $22 \mathrm{a}$ & $186 \mathrm{~d}$ & $161 \mathrm{~b}$ & $89 \mathrm{a}$ & $30.4 \mathrm{c}$ & $3.367 \mathrm{a}$ \\
Preto & $123 \mathrm{a}$ & $102 \mathrm{a}$ & $22 \mathrm{a}$ & $185 \mathrm{~d}$ & $199 \mathrm{a}$ & $84 \mathrm{~b}$ & $24.1 \mathrm{i}$ & $2.087 \mathrm{c}$ \\
Argentino & $125 \mathrm{a}$ & $93 \mathrm{~b}$ & $20 \mathrm{~b}$ & $184 \mathrm{~d}$ & $216 \mathrm{a}$ & $93 \mathrm{a}$ & $30.5 \mathrm{c}$ & $3.638 \mathrm{a}$ \\
Kinsel & $76 \mathrm{~b}$ & $95 \mathrm{~b}$ & $21 \mathrm{~b}$ & $190 \mathrm{c}$ & $198 \mathrm{a}$ & $90 \mathrm{a}$ & $33.1 \mathrm{a}$ & $2.137 \mathrm{c}$ \\
Camilo & $100 \mathrm{a}$ & $105 \mathrm{a}$ & $23 \mathrm{a}$ & $203 \mathrm{a}$ & $149 \mathrm{~b}$ & $86 \mathrm{~b}$ & $32.5 \mathrm{~b}$ & $3.361 \mathrm{a}$ \\
Piriquito & $100 \mathrm{a}$ & $95 \mathrm{~b}$ & $20 \mathrm{~b}$ & $180 \mathrm{~d}$ & $237 \mathrm{a}$ & $93 \mathrm{a}$ & $30.2 \mathrm{c}$ & $4.106 \mathrm{a}$ \\
Casca roxa & $63 \mathrm{~b}$ & $105 \mathrm{a}$ & $21 \mathrm{~b}$ & $185 \mathrm{~d}$ & $141 \mathrm{~b}$ & $91 \mathrm{a}$ & $25.7 \mathrm{~g}$ & $2.482 \mathrm{~b}$ \\
Caipira & $68 \mathrm{~b}$ & $85 \mathrm{c}$ & $22 \mathrm{a}$ & $190 \mathrm{c}$ & $156 \mathrm{~b}$ & $87 \mathrm{a}$ & $27.2 \mathrm{f}$ & $2.728 \mathrm{~b}$ \\
Primavera & $81 \mathrm{~b}$ & $73 \mathrm{~d}$ & $22 \mathrm{a}$ & $201 \mathrm{a}$ & $118 \mathrm{c}$ & $78 \mathrm{~b}$ & $22.3 \mathrm{j}$ & $848 \mathrm{~d}$ \\
Cambará & $46 \mathrm{c}$ & $70 \mathrm{~d}$ & $22 \mathrm{a}$ & $206 \mathrm{a}$ & $101 \mathrm{c}$ & $51 \mathrm{c}$ & $21.6 \mathrm{~K}$ & $654 \mathrm{~d}$ \\
\hline Mean & 84 & 90,2 & 21,7 & 192 & 159 & 85 & 27.7 & 2.303 \\
CV (\%) & 12.2 & 5.82 & 4.39 & 1.41 & 10.1 & 6.82 & 0.64 & 21.5 \\
\hline
\end{tabular}

TIL: number of tillers (tillers $\mathrm{m}^{2}{ }^{2}$ ); HEl: plant height (cm); PAL: panicle lenght (cm); CYC: cycle (days); NPM: number of panicles (panicles $\mathrm{m}^{-2}$ ); PFG: percentage of filled grains (\%); TGM: Thousand grain weight $(\mathrm{g})$; $\mathrm{Y}$ : yield $\left(\mathrm{kg} \mathrm{ha}^{-1}\right)$; Means followed by the same letter, in column, are not different according to the Scott-Knott's test at $5 \%$ of probability. 
the varieties 'Agulha' and 'Rosa 15' were not different from the commercial varieties, which reinforces the adaptation of the local varieties as well as the edaphoclimatic conditions of the region of cultivation of the experiment. The less productive varieties ('Agulha' and 'Rosa 15') were the ones that presented the lowest values for the number of panicles $\mathrm{m}^{2}$ and thousand grains weight, components that can influence the varieties yield.

The average cycle of the varieties was 192 days until harvest, with variations of 180 days ('Piriquito') up to 206 days ('Cambará') (Table 1). The characterization of the cycle of a rice variety is very relative, since this is an inherent characteristic of the variety, but can also be influenced by the environment (Menezes et al., 2011), such as water and nutritional stresses, temperature, solar radiation, among others.

Regarding plant height, based on the classification of Fonseca et al. (2007), the 'Agulha' variety and the commercial varieties 'Primavera' and 'Cambará' were classified as low size (mean height less than $80 \mathrm{~cm}$ ). The varieties 'Gomes', 'Preto', 'Camilo' and 'Casca Roxa' as tall (mean height higher than $100 \mathrm{~cm}$ ) and the other varieties as medium size (mean height of 80 to $100 \mathrm{~cm}$ ) (Table 1). In the organic system, plant height may be an important feature, since tall plants have an advantage in competition with weeds, however, they are more prone to lodge (Fageria, 2007). Despite the observed diversity in size, no lodging problems were observed.

Thousand grain weight was the evaluated variable that presented the greatest diversity among the varieties. The 'Cambará' variety presented the lowest value (21.6g) and the 'Kinsel' the highest value (33.1g) (Table 1). Grain weight is one of the main agronomic variables related to grain yield (Ferrio et al., 2006). High diversity in this character in upland rice cultivars was also observed by Bonow et al. (2007).

According to Ribeiro et al. (2010) indirect selection in the primary components of grain production provides the identification of superior varieties. In addition, the nature of relations between characters, which correlate and indirectly influence of the yield, should be analyzed. However, simple correlation do not determine the relative importance of the direct and indirect influences of these variables on yield (Gondim et al., 2008), only the intensity and direction of the relationship between two or more variables (Yadav et al., 2011). Through path analysis it is possible to know in detail the influence of the characters involved in productivity (Silva et al., 2005).

Estimates of the phenotypic and genotypic correlation coefficients for the evaluated variables allowed the evaluation of the magnitude and direction of the influences of one variable on the other. After track analysis, the concordance of the phenotypic and genotypic correlations with yield $(Y)$ for most of the variables was observed. As for the magnitudes, the genotypic correlations were superior to the phenotypic correlations, however with values of close magnitude, reflecting the small environmental influence on the association of the variables and demonstrating the greater effect of the genotype on the evaluated variables. Regarding the yield components, all variables presented a positive phenotypic and genotypic correlation with yield, as well as direct and indirect positive effects (Table 2). From the correlation estimation, it was observed that some components presented a greater favorable contribution.

The number of panicles $\mathrm{m}^{2}{ }^{2}$ (NPM) was the variable that presented higher values for phenotypic (0.782) and genotypic (0.841) correlations and the higher direct effect on $Y$

Table 2. Estimative of the phenotypic and genotypic correlation coefficients for direct and indirect effects of yield components of rice varieties produced in an organic system, Campos Novos, SC, Brazil, 2011/2012.

\begin{tabular}{ccccccc}
\hline Variables & \multicolumn{2}{c}{ NPM } & \multicolumn{2}{c}{ TGM } & \multicolumn{2}{c}{ PFG } \\
\hline Correlation & PHE & GE & PHE & GE & PHE & GE \\
\hline DE on Y & 0.481 & 0.564 & 0.328 & 0.288 & 0.158 & 0.131 \\
IE via: & & & & & & \\
NPM & - & - & 0.286 & 0.360 & 0.322 & 0.403 \\
TGM & 0.194 & 0.183 & - & - & 0.233 & 0.215 \\
PFG & 0.106 & 0.093 & 0.112 & 0.097 & - & - \\
\hline Total & 0.782 & 0.841 & 0.726 & 0.745 & 0.714 & 0.749 \\
\hline
\end{tabular}

PHE: phenotypic correlation; GE: genotypic correlation; DE: direct effect; IE: indirect effect; Y: yield (kg ha $\left.{ }^{-1}\right)$; NPM: number of panicles $\mathrm{m}^{2}{ }^{2}$; TGM: thousand grain weight; ' $\mathrm{PFG}$ : percentage of full grains. 
( 0.481 and 0.564 respectively), indicating that this component presented higher relation with $Y$ and that varieties that resulted in higher NPM were the most productive ones.

For thousand grain weight (TGM), it was observed a phenotipic (0.726) and genotypic (0.745) correlation and positive direct effects, but with lower intensity (0.328 e 0.288 respectively). The percentage of filled grains (PFL) presented lower but positive correlation values (phenotypic: 0.714 and genotypic 0.749) and the lower values of direct effects $(0.158$ and 0.131 , respectively). These results are in accordance with Krishnan \& Surya Rao, (2005), who obtained similar results when evaluated 12 rice genotypes in three crop years, concluding the higher yield of certain genotypes is correlated with the higher number of panicles $\mathrm{m}^{2}$ and to the higher proportion of grains with higher density, and also that these variables can be affected by the field growing environment.

According to Fageria (2007), the variation in productivity due to yield components is given by the following order: number of panicles per area> percentage of full grains> grains weight. The study of Jambhulkar \& Bose (2014), Seesang et al. (2013) and Zahid et al. (2006), point out that for the increase of grain yield in rice genotypes, variables such as the number of grains per panicle and the thousand grains mass must be observed.

Different reports verified, during four harvests of rice production, that the thousand grains weight was the component of production with higher effect in increasing the crop yield, and the number of not filled panicles influenced most the reduction (Marchezan et al., 2005). Similar results were reported by Guimarães et al. (2008), with 5 rice cultivars, where the production of more productive cultivars was due to the increase of the harvest index and the grain weight, and the reduction of the panicle sterility.

Plant height (HEI) showed a high genotypic (0.756) and phenotypic (0.728) correlation with yield $(Y)$, and higher direct effects (0.984 and 0.632 respectively), indicating that the varieties with higher $\mathrm{HEl}$ values were the most productive ones (Table 3). Jambhulkar \& Bose (2014) concluded that this positive relationship of height and yield may depend on the genotype used, when evaluating 22 upland rice genotypes, observing positive association with plant height and yield. However, other authors, such as Tehrim et al. (2012) evaluating a group of 68 commercial and traditional rice varieties observed a negative correlation between plant height and grain yield.

According to Zia-Ul-Qamar et al. (2005) and Seesang et al. (2013) the number of productive tillers is one of the most important characteristics that should be considered for improving rice yield. Due to the emission of tillers, a compensation occurs between the rice plants, with adjustment in the plant density, number of tillers per plant and number of panicles per plant, so that the number of panicles and grains per area is constant (Guimarães et al., 2008, Fageria, 2007). Plants with high tillering capacity are able to use all available space and resources (Fageria, 2007). Akhtar al. (2011) and Agahi et al. (2007) identified through strong path analysis the association and direct effect of the number of tillers on the rice yield, as well as the number of filled grains per panicle and thousand grain mass.

Table 3. Estimative of the phenotypic and genotypic correlation coefficients for direct and indirect effects of components and cycle on the yield of rice varieties produced in an organic system, Campos Novos, SC, Brazil, $2011 / 2012$.

\begin{tabular}{lcccccccc}
\hline Variables & \multicolumn{2}{c}{ TIL } & \multicolumn{2}{c}{ HEI } & \multicolumn{2}{c}{ PAL } & \multicolumn{2}{c}{ CYC } \\
\hline Correlation & PHE & GE & PHE & GE & PHE & GE & PHE & GE \\
\hline DE on Y & 0.268 & 0.243 & 0.632 & 0.984 & -0.306 & -0.728 & 0.018 & 0.511 \\
IEvia: & & & & & & & & \\
TIL & - & - & 0.150 & 0.151 & -0.047 & -0.039 & -0.114 & -0.109 \\
HEI & 0.355 & 0.611 & - & - & 0.092 & 0.138 & -0.343 & -0.535 \\
PAL & 0.054 & 0.119 & 0.044 & -0.102 & - & - & -0.151 & -0.511 \\
CYC & 0.007 & -0.229 & -0.009 & -0.277 & 0.009 & 0.358 & - & - \\
\hline Total & 0.669 & 0.745 & 0.728 & 0.756 & 0.252 & -0.272 & -0.590 & -0.644 \\
\hline
\end{tabular}

PHE: phenotypic correlation; GE: genotypic correlation; DE: direct effect; IE: indirect effect; Y: yield ( $\left.\mathrm{kg} \mathrm{ha}^{-1}\right)$; TIL: number of tillers $\mathrm{m}^{-2}$; HEl: plant height ( $\mathrm{cm}$ ); PAL: panicle length ( $\left.\mathrm{cm}\right)$; CYC: cycle (days). 
Experiments for the crop years 2 and 3: characterization and yield of upland rice varieties under conventional and organic cultivation

The mean yield of the experiment was $1.711 \mathrm{~kg} \mathrm{ha}{ }^{-1}$ during the second year of production and $3.534 \mathrm{~kg} \mathrm{ha}^{-1}$ during the third, values that are lower and above the observed during the variety characterization $12.303 \mathrm{~kg}$ $\mathrm{ha}^{-1}$ ) (Table 4). The difference observed in the yield for the two harvests can be explained by the environmental conditions variation, mainly regarding temperature.

Steinmetz et al. (2006) affirm that air temperature is one of the most important climatic elements for the growth, development and productivity of rice cultivation. According to Steinmetz et al. (2006), the solar radiation and the air temperature during the reproductive phase are determinant to obtain high grain yields in the rice crop, and the optimum temperature is between 20 and $35^{\circ} \mathrm{C}$ during germination, 30 and $33^{\circ} \mathrm{C}$ during flowering and between 20 and $25^{\circ} \mathrm{C}$ for the grain maturation.

During the experiments for evaluation of the varieties, average temperatures were lower than the required by the crop. During the second crop year (2), the mean temperature in the sowing period until emergence was $19^{\circ} \mathrm{C}$, from emergence to flowering of $21^{\circ} \mathrm{C}$ and from flowering to harvest was $18^{\circ} \mathrm{C}$, and with registers with minimum temperature about $10^{\circ} \mathrm{C}$. In this harvest, the grain yield was lower due to the high percentage of sterile panicles, caused by the occurrence of low temperatures during the grain filling phase. The varieties that presented the highest yields in the second crop year (2) were those with the shortest cycle and the highest percentages of full grains, due to the fact that in these varieties the period of filling grains occurred before the period when there was a higher occurrence of low temperature (Figure 01).

In third crop year (3), the mean temperature in the period from sowing to emergence was $17^{\circ} \mathrm{C}$, from emergence to flowering $21^{\circ} \mathrm{C}$ and from flowering to harvest, $20^{\circ} \mathrm{C}$. In this crop, even with the average temperature during grains filling below the optimum, it remained about $20^{\circ} \mathrm{C}$ (Figure 01). Seeding was carried out 11 days before when compared to the crop year 2, which may have contributed to the higher productivity of the varieties due to the advanced cycle, so that grain filling and maturation occurred with higher temperatures (near the ideal $-20^{\circ} \mathrm{C}$ ), resulting in a higher percentage of full grains (PFG) and grain weight (GM).

Comparing the producing years (2 and 3), it was observed that the anticipation of sowing date and the occurrence of higher and more stable temperatures contributed to the reduction of varieties cycle and the grain yield increase. In the two harvests the varieties presented similar sowing-flowering period (FLO) (125 and 122 days respectively). The difference observed in the cycle occurred during the period of grain filling until maturation, since the occurrence of lower temperatures causes the reduction in grains dry matter accumulation, in the filling period and slower maturation. This was similar to that observed by other authors, where the grain formation and filling period occurred between 30 and 40 days, with little influence of the cultivar cycle (SOSBAI, 2012).

In addition to being influenced by climatic conditions, yield is mainly a consequence of the association of different income components, as verified in different years. In the third crop year (3), where yields were higher, the varieties presented the highest NPM (number of panicles $\mathrm{m}^{2}$ : 196), the highest TGW (thousand grain weight: $28.9 \mathrm{~g}$ ) and also high PFG (percentage of full grains: $84 \%)$. In the $2^{\text {nd }}$ year of production (2), when the lowest yield was obtained, the varieties produced higher NPM (180), high TGW (27.7g) and the lowest PFG (51\%), being the last one the component that limited the varieties yield, which was caused by the occurrence of low temperatures during grain filling. The thousand grain weight and the percentage of full grains are the main characteristics for yield of the rice crop (Fageria, 2007).

At the first crop year (1), a lower yield was observed due to the lower NPM (159), variable with high association with these varieties yield. NPM was limited by the lower tillering of the varieties in this crop, which is reduced with lower temperatures. In addition, the weeds development is more accelerated and may 
cause competition with the crop, causing losses in productivity, which was not observed in this experiment.

The plants presented a mean height of $98 \mathrm{~cm}$ (ranging from 79 to $109 \mathrm{~cm}$ ) during the $2^{\text {nd }}$ cycle, and of $96 \mathrm{~cm}$ (ranging from 86 to $107 \mathrm{~cm}$ ) during the $3^{\text {rd }}$ cycle (Table 4), and in both crop years the average was higher than the observed for the first crop year (1: $90 \mathrm{~cm})$ (Table 1). Even with plants with higher height, it was not observed problems with lodging.

As already observed in the varieties characterization, the thousand grain weight (TGW) was the characteristic that presented greater diversity between the varieties in the two harvests. In the second year of production, the

Table 4. Agronomic characterization of 13 upland rice varieties under conventional (CO) and organic (OR) system of production. Campos Novos, SC, Brazil, 2012/2013 and 2013/2014 crop years.

\begin{tabular}{|c|c|c|c|c|c|c|c|c|c|c|c|c|c|}
\hline \multirow{3}{*}{$\begin{array}{l}\text { Variety } \\
\text { Harvest } \\
\text { System }\end{array}$} & \multicolumn{3}{|c|}{ EME } & \multicolumn{2}{|c|}{ TIL } & \multicolumn{2}{|c|}{$\mathrm{HEI}$} & \multicolumn{2}{|c|}{ PAL } & \multicolumn{2}{|c|}{ FLO } & \multicolumn{2}{|c|}{ CYC } \\
\hline & \multicolumn{2}{|c|}{2} & \multirow{2}{*}{3} & \multirow{2}{*}{2} & \multirow{2}{*}{3} & \multirow{2}{*}{2} & \multirow{2}{*}{3} & \multirow{2}{*}{2} & \multirow{2}{*}{3} & \multirow{2}{*}{2} & \multirow{2}{*}{3} & \multirow{2}{*}{2} & \multirow{2}{*}{3} \\
\hline & $\mathrm{CO}$ & OR & & & & & & & & & & & \\
\hline Agulha & $88 a A$ & $90 a A$ & $88 a$ & $248^{a}$ & $252 a$ & $95 \mathrm{c}$ & $91 \mathrm{c}$ & $22 a$ & $21 b$ & $128 c$ & $123 d$ & $184 a$ & $173^{a}$ \\
\hline Rosa 15 & $84 a B$ & $96 a A$ & $72 b$ & $264^{a}$ & $208 b$ & $113 a$ & $100 b$ & $22 a$ & $21 b$ & $124 c$ & $118 e$ & $174 \mathrm{C}$ & $165 b$ \\
\hline Mato Grosso & $70 c B$ & $86 a A$ & $79 a$ & $232 b$ & $242 a$ & $88 d$ & $95 c$ & $20 b$ & $22 a$ & $124 c$ & $118 e$ & $174 \mathrm{C}$ & $164 b$ \\
\hline Gomes & $84 a A$ & $91 \mathrm{aA}$ & $85 a$ & $229 b$ & $207 b$ & $109 a$ & $102 b$ & $21 a$ & $23 a$ & $120 d$ & $118 e$ & $168 d$ & $156 \mathrm{C}$ \\
\hline Preto & $79 \mathrm{bA}$ & $75 \mathrm{bA}$ & $89 a$ & $268 a$ & $261 a$ & $108 a$ & $107^{a}$ & $21 a$ & $22 a$ & $136 b$ & $130 a$ & $173 c$ & $166 b$ \\
\hline Argentino & $65 \mathrm{cB}$ & $78 \mathrm{bA}$ & $87 a$ & $217 b$ & $188 b$ & $94 c$ & $90 c$ & $20 \mathrm{~b}$ & $20 b$ & $117 d$ & $118 e$ & $170 d$ & $148 d$ \\
\hline Kinsel & $68 c B$ & $87 a A$ & $80 a$ & $241 b$ & $198 b$ & $93 c$ & $92 c$ & $20 b$ & $21 b$ & $118 d$ & $118 e$ & $170 d$ & $148 d$ \\
\hline Camilo & $78 \mathrm{bA}$ & $86 a A$ & $84 a$ & $258 a$ & $223 b$ & $102 a$ & $100 b$ & $21 a$ & $20 b$ & $139 a$ & $132 a$ & $187 a$ & $172^{a}$ \\
\hline Piriquito & $73 c B$ & $90 a A$ & $82 a$ & $271 a$ & $234 a$ & $97 c$ & $92 c$ & $20 b$ & $21 b$ & $120 d$ & $119 a$ & $168 d$ & $158 \mathrm{C}$ \\
\hline Casca Roxa & $79 \mathrm{bA}$ & $80 \mathrm{bA}$ & $73 b$ & $211 b$ & $206 b$ & $108 a$ & $107^{a}$ & $22 a$ & $20 b$ & $133 b$ & $128 b$ & $173 c$ & $165 b$ \\
\hline Caipira & $90 \mathrm{aA}$ & $92 a A$ & $81 a$ & $281 a$ & $221 b$ & $97 c$ & $98 b$ & $21 a$ & $22 a$ & $127 c$ & $124 c$ & $180 b$ & $165 b$ \\
\hline Primavera & $89 a A$ & $93 a A$ & $79 a$ & $253 a$ & $233 a$ & $87 d$ & $90 c$ & $22 a$ & $22 a$ & $120 d$ & $118 e$ & $181 b$ & $169^{a}$ \\
\hline Cambará & $76 \mathrm{CB}$ & $95 a A$ & $66 \mathrm{~b}$ & $251 a$ & $216 b$ & $79 e$ & $86 c$ & $20 \mathrm{~b}$ & $23 a$ & $124 \mathrm{c}$ & $120 e$ & $187 a$ & $168 \mathrm{~b}$ \\
\hline Mean & 79 & 88 & 80 & 247 & 222 & 98 & 96 & 21 & 22 & 125 & 122 & 176 & 163 \\
\hline $\mathrm{CV}$ & 10.0 & 5.81 & 7.88 & 7.41 & 8.34 & 6.82 & 5.65 & 4.87 & 10.4 & 1.62 & 0.73 & 1.15 & 1.85 \\
\hline
\end{tabular}

Table 5. Agronomic characterization of 13 upland rice varieties under conventional (CO) and organic (OR) system of production. Campos Novos, SC, Brazil, 2012/2013 and 2013/2014 crop years.

\begin{tabular}{|c|c|c|c|c|c|c|c|c|c|c|c|c|c|}
\hline \multirow{3}{*}{$\begin{array}{l}\text { Variety } \\
\text { Harvest } \\
\text { System }\end{array}$} & \multicolumn{2}{|c|}{ NPM } & \multicolumn{2}{|c|}{ NGP } & \multicolumn{2}{|c|}{ PGC } & \multicolumn{4}{|c|}{ MMG } & \multicolumn{3}{|c|}{ PRD } \\
\hline & \multirow{2}{*}{2} & \multirow{2}{*}{3} & \multirow{2}{*}{2} & \multirow{2}{*}{3} & \multirow{2}{*}{2} & \multirow{2}{*}{3} & \multicolumn{2}{|r|}{2} & \multicolumn{2}{|c|}{3} & & \multicolumn{2}{|c|}{3} \\
\hline & & & & & & & $\mathrm{CO}$ & OR & $\mathrm{CO}$ & OR & & $\mathrm{CO}$ & OR \\
\hline Agulha & $176 b$ & $189 a$ & $166^{a}$ & $135 b$ & $47 c$ & $79 c$ & $27.7 e A$ & $26.2 \mathrm{hB}$ & $27.6 f \mathrm{~A}$ & $26 . \lg B$ & $1.419 c^{2}$ & $3.719 a A^{2}$ & $3.711 \mathrm{aA}^{2}$ \\
\hline Rosa 15 & $192 a$ & $224 a$ & $138 b$ & $122 \mathrm{c}$ & $48 c$ & $84 c$ & $27.3 f A$ & $27.2 \mathrm{gA}$ & $29.9 \mathrm{dA}$ & $26.8 \mathrm{fB}$ & ${ }^{1} 1.957 b^{2}$ & $4.176 a A^{2}$ & $3.729 a A^{2}$ \\
\hline Mato Grosso & $175 b$ & $197 a$ & $129 b$ & $117 c$ & $63 b$ & $90 b$ & $27.7 e B$ & $28.7 f A$ & $30.0 \mathrm{dA}$ & $28.9 e B$ & ${ }^{1} 1.795 b^{2}$ & $3.423 \mathrm{bA}$ & $13.454 \mathrm{aA}$ \\
\hline Gomes & $181 b$ & $208 a$ & $126 b$ & $129 c$ & $71 b$ & $86 b$ & $35.1 \mathrm{aA}$ & 33.7aB & $33.2 \mathrm{bA}$ & $29.2 \mathrm{~dB}$ & $12.271 \mathrm{a}^{2}$ & $3.234 \mathrm{bA}$ & $3.644 \mathrm{aA}^{2}$ \\
\hline Preto & $165 b$ & $211 a$ & $141 \mathrm{~b}$ & $99 d$ & $31 d$ & $83 c$ & 22.5jA & 21.9jB & $28.8 \mathrm{eA}$ & 27. $\mathrm{OfB}$ & $907 d$ & $2.531 \mathrm{cA}$ & ${ }^{1} 2.349 \mathrm{CA}$ \\
\hline Argentino & $166 b$ & $176 a$ & $104 c$ & $123 c$ & $77 a$ & $93 a$ & $32.7 \mathrm{bA}$ & $32.6 \mathrm{bA}$ & $32.6 \mathrm{cA}$ & $32.1 \mathrm{fB}$ & ${ }^{1} 2.301 a^{2}$ & $3.395 \mathrm{bB}$ & $4.069 a A^{2}$ \\
\hline insel & $193 a$ & $191 a$ & $100 c$ & $118 c$ & $78 a$ & $93 a$ & 32.7bA & $32.2 \mathrm{CB}$ & $33.5 \mathrm{bA}$ & $32.7 \mathrm{bB}$ & ${ }^{1} 2.408 a^{2}$ & $3.310 \mathrm{bB}$ & $3.939 \mathrm{aA}^{2}$ \\
\hline Camilo & $157 b$ & $162 a$ & $165^{a}$ & $116 \mathrm{c}$ & $49 c$ & $87 b$ & $31.7 \mathrm{cA}$ & $30.3 \mathrm{~dB}$ & $34.8 \mathrm{aA}$ & $35.2 \mathrm{aA}$ & $1.292 c^{2}$ & $3.857 a A^{2}$ & $3.983 \mathrm{aA}^{2}$ \\
\hline Piriquito & $217 a$ & $214 a$ & $107 c$ & $102 d$ & $70 b$ & $80 c$ & $29.7 \mathrm{dA}$ & $29.8 \mathrm{eA}$ & $33.6 \mathrm{bA}$ & $30.6 \mathrm{cB}$ & ${ }^{1} 2.722 a^{2}$ & $3.780 \mathrm{aA}^{2}$ & $3.906 \mathrm{aA}^{2}$ \\
\hline Casca roxa & $154 b$ & $174^{a}$ & $161^{a}$ & $113 c$ & $53 c$ & $92 a$ & 24.1hA & $21.11 \mathrm{~B}$ & $26.4 \mathrm{gA}$ & $24.7 \mathrm{hB}$ & ${ }^{1} 1.858 b^{2}$ & $3.640 \mathrm{aA}^{2}$ & $12.438 c B$ \\
\hline Caipira & $172 b$ & $190^{a}$ & $168^{a}$ & $140 b$ & $48 c$ & $81 c$ & $26.9 \mathrm{gA}$ & $26.1 \mathrm{hB}$ & $28.2 \mathrm{eA}$ & $28.2 \mathrm{eA}$ & ${ }^{1} 1.679 b^{2}$ & $3.989 a A^{2}$ & $4.140 \mathrm{aA}^{2}$ \\
\hline Primavera & $206 a$ & $224^{a}$ & $189^{a}$ & $159 a$ & $18 e$ & $69 d$ & 23.0iB & 24.3iA & $23.5 \mathrm{hB}$ & $24.0 \mathrm{iA}$ & $1.008 d$ & $3.521 \mathrm{bB}$ & $4.211 \mathrm{aA}$ \\
\hline Cambará & $198 a$ & $192^{a}$ & $192^{a}$ & $160 a$ & $16 e$ & $72 d$ & $21.61 \mathrm{~A}$ & $21.3 \mathrm{IB}$ & $22.4 \mathrm{iA}$ & $21.7 \mathrm{jB}$ & $631 d$ & $2.504 \mathrm{cA}$ & $2.962 \mathrm{bA}$ \\
\hline$\overline{M e a n}$ & 180 & 196 & 142 & 126 & 51 & 84 & 27.9 & 27.4 & 29.6 & 28.3 & 1.711 & 3.468 & 3.580 \\
\hline CV (\%) & 8.16 & 11.2 & 8.54 & 7.99 & 9.39 & 6.47 & 0.51 & 0.76 & 0.92 & 1.18 & 24.5 & 13.2 & 9.12 \\
\hline
\end{tabular}

NPM: number of panicles per meter (panicles $\mathrm{m}^{2}{ }^{2}$ ); NGP: number of grains per panicle (grain panicle-1); PFG: percentage of full grains (\%); TGW: thousand grain weigh (g); Y: yield $\left(\mathrm{kg} \mathrm{ha}^{-1}\right)$. Averages followed by the same lowercase letter in the column are not different according to Scott-Knott's test at $5 \%$ of probability; averages followed by the same capital letter within the same variable, in the line are not different according to the Tukey's test at $5 \%$ probability. 'Different from the commercial variety 'Primavera' - according to Dunnet's test at $5 \%$ of probability. ${ }^{2}$ Different from the commercial variety - ' Cambará, according to Dunnett's test at $5 \%$ of probability. 

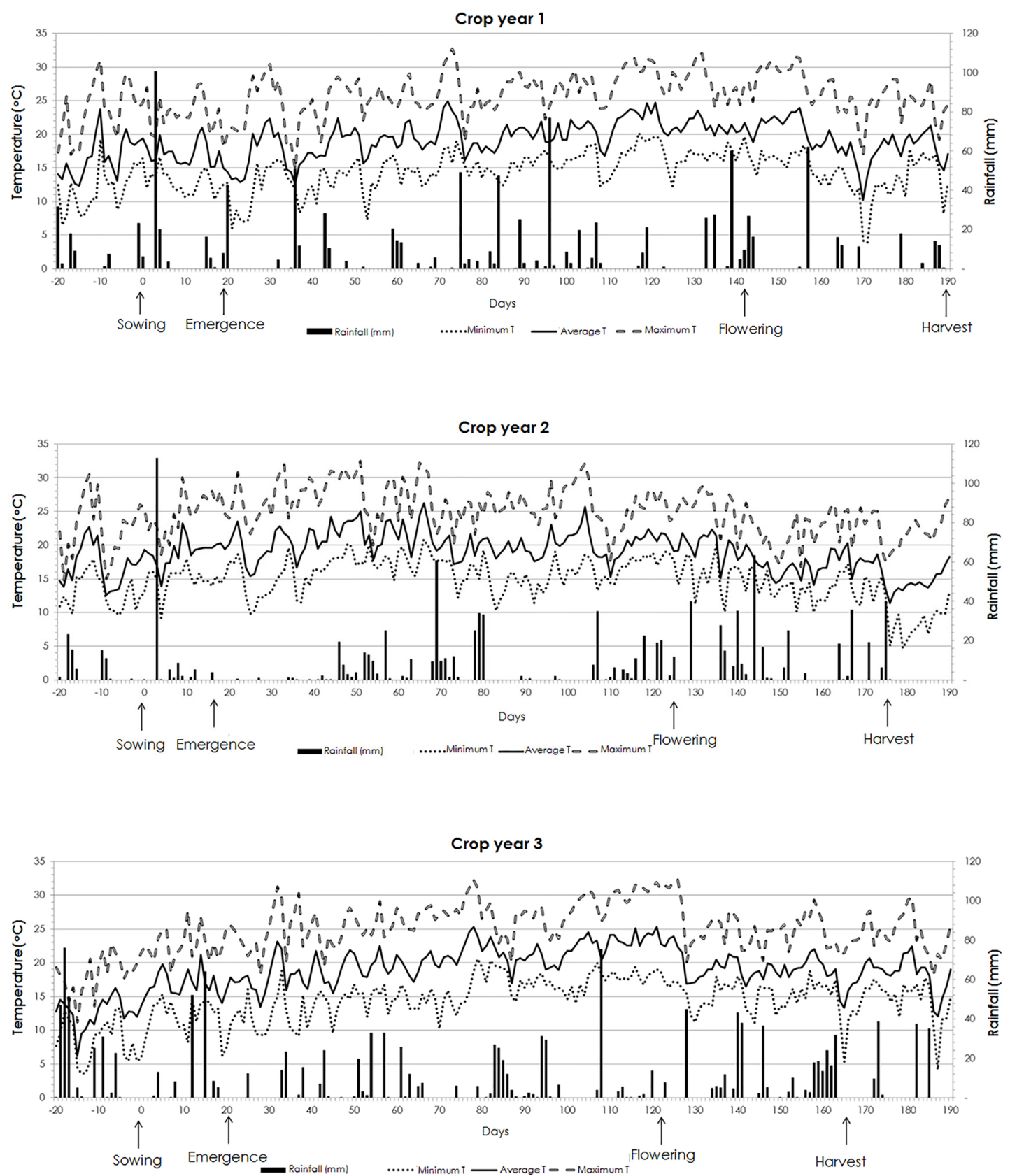

Figure 1. Daily maximum, average and minimum temperatures $\left({ }^{\circ} \mathrm{C}\right)$ and rainfall $(\mathrm{mm})$ registered at the EPAGRI meteorological station, Campos Novos, SC, Brazil, from sowing to harvest of the crop years 2011/2012 (1), 2012/2013 (2) and $2013 / 2014$ (3).

varieties averaged $27.7 \mathrm{~g}$ and the 'Gomes' variety produced heavier grains in the two cropping systems and during the third year of production, the average TGM was $28.9 \mathrm{~g}$ and the 'Camilo' variety presented the highest values, differing from the $1^{\text {st }}$ harvest, when the higher TGM was observed in the 'Kinsel' variety (Table 4).

Regarding the varieties, it was observed that the 'Piriquito' variety presented higher yields for the years of production and cropping systems. The varieties 'Gomes', 'Argentino' and 'Kinsel' presented higher yields during the $2^{\text {nd }}$ year of production, with adverse environmental conditions and with higher productivity when compared to commercial varieties during the same year, probably due to the greater rusticity of the cited materials. The varieties 'Agulha', 'Rosa 15', 'Camilo' and 'Caipira' presented good productive potential in both cropping systems during the $3^{\text {rd }}$ crop year, with favorable 
environmental conditions.

In order to verify the relative contribution of each variable to the genetic dissimilarity, by the method proposed by SINGH (1981), it was identified variability among the evaluated characters, being the TGM the character that presented the greater variation, and greater contribution to the divergence between the varieties, for both harvests and systems of cultivation.

By cluster analysis using the Tocher optimization method, the varieties were separated into distinct groups, according to the crop and cropping system (Table 5). For the $2^{\text {nd }}$ year of production, all varieties showed different behavior in the different cropping systems. However, during the $3^{\text {rd }}$ year of production, the varieties 'Caipira', 'Mato Grosso' and 'Rosa 15' (group 1) presented similar behavior in both cropping systems. In relation to the cultivation systems, the varieties 'Piriquito' (group 2), 'Primavera' (group 3) and 'Cambará' (group 3) presented similar behavior in conventional cultivation, and the varieties 'Caipira' and 'Rosa 15' (group 1) for the organic cultivation in the two crop years.

The local evaluated varieties presented satisfactory yield for both evaluated systems of production, showing their potential in the evaluated region. Although the varieties presented good levels of productivity, a high variability was observed in the two harvests, caused mainly by the climatic conditions. The sowing time was one of the factors that influenced most the varieties yield due to the sensitivity of the plant to adverse environmental factors, especially regarding air temperature. Thus, sowing must be carried out in a moment that allows the coincidence of the filling and maturation phases of grains with periods of low probability of occurrence of low temperatures.

The agronomic performance of the local varieties was efficient when grown in an organic system of production, which favors its maintenance and its high promising potential use, demonstrating a high genetic contribution to the evaluated agronomic variables. As it is an autogamous species, there are strong indications that within the population there is already genetic stability, and also because it has already undergone a selection process, realized by growers.

Table 6. Grouping by the Tocher optimization method of 13 upland rice varieties grown in organic and conventional systems. Campos Novos, SC, Brazil, 2012/2013 and 2013/2014 crop years.

\begin{tabular}{|c|c|c|c|c|}
\hline \multirow[b]{2}{*}{ Group } & \multicolumn{2}{|c|}{ Harvest 2} & \multicolumn{2}{|r|}{ Harvest 3} \\
\hline & Conventional & Organic & Conventional & Organic \\
\hline 1 & $\begin{array}{l}\text { Argentino, Kinsel, } \\
\text { Camilo }\end{array}$ & $\begin{array}{l}\text { Agulha, Caipira, } \\
\text { Rosa } 15\end{array}$ & $\begin{array}{l}\text { Agulha, Caipira, Preto, } \\
\text { Mato Grosso, Rosa } 15\end{array}$ & $\begin{array}{l}\text { Argentino, Kinsel, Piriquito, Gomes, } \\
\text { Mato Grosso, Caipira, Rosa } 15\end{array}$ \\
\hline 2 & $\begin{array}{l}\text { Rosa 15, Caipira, } \\
\text { Agulha, Mato } \\
\text { Grosso, Piriquito }\end{array}$ & $\begin{array}{l}\text { Argentino, Kinsel, } \\
\text { Gomes }\end{array}$ & $\begin{array}{l}\text { Argentino, Kinsel, Gomes } \\
\text { Piriquito }\end{array}$ & $\begin{array}{l}\text { Agulha, Primavera, Casca roxa, } \\
\text { Preto }\end{array}$ \\
\hline 3 & $\begin{array}{l}\text { Primavera, } \\
\text { Cambará, Preto, } \\
\text { Casca roxa }\end{array}$ & $\begin{array}{l}\text { Mato Grosso, } \\
\text { Piriquito, Camilo }\end{array}$ & Primavera, Cambará & Cambará \\
\hline 4 & Gomes & $\begin{array}{l}\text { Preto, Casca roxa, } \\
\text { Cambará }\end{array}$ & Casca roxa & Camilo \\
\hline 5 & & Primavera & Camilo & \\
\hline
\end{tabular}

\section{Conclusions}

1. There is genetic diversity between varieties for all evaluated variables.

The thousand grain weight was the variable that influenced most the divergence between the varieties.

3. The number of panicles $\mathrm{m}^{-2}$ is the yield component that contributed most to the varieties grain yield under organic system of cultivation, indicating that this is an important characteristic when choosing varieties aiming the yield increase.

4. The varieties, 'Piriquito', 'Argentino', 'Gomes' and 'Kinsel' presented yields higher than $2,000 \mathrm{~kg} \mathrm{ha}^{-1}$ for all evaluated crop years and systems of production. 
5. Most of the varieties presented higher yield when compared to the average yield of rainfed rice produced in the Santa Catarina State, Brazil $\left(1,400 \mathrm{~kg} \mathrm{ha}^{-1}\right)$ in organic and conventional systems. The highest yields were obtained in the crops with earlier sowing and temperatures during grain maturation about $20^{\circ} \mathrm{C}$.

\section{Acknowledgments}

To CNPq for the financial support (Call 58, grant $n^{\circ}$ 563920/2010-6). To FUMDES for the scholarship for the first author. To the National Council of Scientific and Technological Development (CNPq), for the 'PQ2' scholarship for the $2^{\text {nd }}$ and $7^{\text {nd }}$ authors. To the Santa Catarina State Foundation for the research and innovation support (FAPESC no 10.043/2012-9) and PAPFAPESC-CP 04/2014 2015 TR 649/FAPESC TR6532017 for the financial support.

\section{References}

Agahi, K., Fotokian, M.H., Ezatollah, F. 2007. Correlation and Path Coefficient Analysis for Some Yield-Related Traits in Rice Genotypes (Oryza sativa L.). Asian Journal of Plant Sciences 6: 513-517.

Akhtar, N., Nazir, M.F., Safdar, A., Asif, T., Rehman, M.E., Rabnawaz, M., Mahmood, A. 2011. Estimation of Heritability, Correlation and Path Coefficient Analysis in Fine Grain Rice (Oryza sativa L.). Journal of Animal and Plant Sciences 21: 660-664.

Alvarez, R.C.F., Crusciol, C.A.C., Nascente, A.S., Rodrigues, J.D., Habermann, G. 2012. Gas exchange rates, plant height, yield components, and productivity of upland rice as affected by plant regulators. Pesquisa Agropecuária Brasileira 47: 1455-1461.

Amorim, E.P., Ramos, N.P., Ungaro, M.R.G., Kiihl, T. A.M. 2008. Correlações e análise de trilha em girassol. Bragantia 67:307-316.

Bonow, S., Von Pinho, E.V.R., Soares, A.A., Siecola Junior, S. 2007. Caracterização morfológica de cultivares de arroz visando a certificação da pureza varietal. Ciência e Agrotecnologia 31: 619-627.

Cargnelutti Filho, A., Ribeiro, N. D., Jost, E. 2006. Número necessário de experimentos para a comparação de cultivares de feijão. Ciência Rural, Santa Maria 36: 1701-1709.

Cruz, C.D. 2008. Programa Genes - Diversidade Genética. Universidade Federal de Viçosa, Viçosa, Brasil. 278p.
EMBRAPA ARROZ E FEIJÃO. 2016. Dados conjunturais da produção de arroz (Oryza sativa L.) no Brasil (1986 a 2015): área, produção e rendimento. Santo Antônio de Goiás: Embrapa Arroz e Feijão, Disponível em: <http://www. cnpaf.embrapa.br/socioeconomia/index.htm>. Acesso em: 24 out. 2016.

Fageria, N.K. 2007. Yield Physiology of Rice. Journal of Plant Nutrition 30:843-879.

Ferrio, J.P., Alonso, N., Voltas, J., Araus, J.I. 2006. Grain weight changes over time in ancient cereal crops: Potential roles of climate and genetic improvement. Journal of Cereal Science 44:323-332.

Fonseca, J.R., Castro, E. da M. de, Morais, O.P. de, Soares, A.A., Pereira, J.A., Lobo, V.L. da S., Resende, J.M. 2007. Descrição morfológica, agronômica, fenológica e culinária de alguns tipos especiais de arroz (Oryza sativa L.). <http://www.cnpaf.embrapa.br/transferencia/ informacoestecnicas/publicacoesonline/ seriedocumentos_210.pdf>. Acesso em 10 out. 2014.

Gonçalves, G.M.B., Souza, R., Cardozo, A.M., Lohn, A.F., Canci, A., Guadagnin, C.A., Ogliari, J.B. 2011. Análise da diversidade de variedades locais de arroz de sequeiro do Oeste de Santa Catarina. Cadernos de Agroecologia 6:1-4.

Gondim, T.C.O., Rocha, V.S., Sediyama, C., Miranda, G.V. 2008. Análise de trilha para componentes do rendimento e caracteres agronômicos de trigo sob desfolha. Pesquisa Agropecuária Brasileira 43:487-493.

Guimarães, C.M., Stone, L.F., Neves, P.C.F. 2008. Eficiência produtiva de cultivares de arroz com divergência fenotípica. Revista Brasileira de Engenharia Agrícola e Ambiental 12:465-470.

Guimarães, C.M., Stone, L.F., Oliveira, J.P., Rangel, P.H.N., Rodrigues, C.A.P. 2011 . Sistema radicular do arroz de terras altas sob deficiência hídrica. Pesquisa Agropecuária Tropical 41:126-134.

Jambhulkar, N.N., Bose, L.K. 2014. Genetic Variability and Association of Yield Attributing Traits With Grain Yield in Upland Rice. Genetika 46:831-838.

Krishnan, P., Surya Rao, A.V. 2005. Effects of genotype and environment on seed yield and quality of rice. Journal of Agricultural Science 143:283-292.

Marchezan, E., Martin, T.N., Santos, F.M., Camargo, E.R. 2005. Análise de coeficiente de trilha para os componentes de produção em arroz. Ciência Rural 35:1027-1033. 
Menezes, B.R.S., Moreira, L.B., Lopes, H.M., Pereira, M.B. 2011. Caracterização morfoagronômica em arroz vermelho e arroz de sequeiro. Pesquisa Agropecuária Tropical 41:490-499.

Ribeiro, N.D., Cargnelutti Filho, A., Poersch, N.L., Rosa, D.P. 2010. Critério de seleção indireta para a produtividade de grãos em feijão. Ciência Rural 40:986-989.

Seesang, J., Sripicchitt, P., Somchit, P., Sreewongchai, T. 2013. Genotypic Correlation and Path Coefficient for Some Agronomic Traits of Hybrid and Inbred Rice (Oryza sativa L.) Cultivars. Asian Journal of Crop Science 5: 319-324.

Silva, S.A., Carvalho, F.I.F., Nedel, J.L., Cruz, P.J., Silva, J.A.G., Caetano, V.R., Hartwig, I., Sousa, C.S. 2005. Análise de trilha para os componentes de rendimento de grãos em trigo. Bragantia 64:191-196.

Singh, D. 1981. The relative importance of characters affecting genetic divergence. The Indian Journal of Genetic and Plant Breeding 36: 237-245.

SOSBAI. Sociedade Sul-Brasileira de Arroz Irrigado. 2012. Arroz irrigado: recomendações técnicas da pesquisa para o Sul do Brasil. SOSBAI, Pelotas, Brasil. $176 \mathrm{p}$.

Steinmetz, S., Silva, S. C. da, Santana, N. M. P. de. 2006. Clima. In: Santos, A. B., Stone, L. F., Vieira, N. R. de A. A cultura do arroz no Brasil. Embrapa arroz e Feijão, Santo Antônio de Goiás, Brasil. p. 117-160.

Tehrim, S., Pervaiz, Z.H., Mirza Y., Rabbani, A., Masood, S. 2012. Assessment of Phenotypic Variability in Rice (Oryza Sativa L.) Cultivars Using Multivariate Analysis. Pakistan Journal of Botany 44:999-1006.

Yadav, S.K., Pandey, P., Kumar, B., Suresh, B.G. 2011. Genetic Architecture, Inter-relationship and Selection Criteria for Yield Improvement in Rice (Oryza sativa L.). Pakistan Journal of Biological Sciences 14: 540-545.

Zahid, M.A., Akhter, M., Sabar, M., Manzoor, Z., Awan, T. 2006. Correlation and path analysis studies of yield and economic traits in basmati rice (Oryza sativa L.). Asian Journal of Plant Sciences 5: 643-645.

Zia-Ul-Qamar, Cheema, A.A., Ashraf, M., Rashid, M., Tahir, G.R. 2005. Association Analysis of Some Yield Influencing Traits in Aromatic and Non Aromatic Rice. Pakistan Journal of Botany 37:613627. 